\title{
Three Illuminated Videos
}

SPECIAL

COLLECTION:

SPECIAL ISSUE OF

ILLUMINATED VIDEOS

VIDEO ARTICLE

KYLE BARRETT (1)

ILONA KRAWCZYK (1)

CHARLOTTA GRIMFJORD CEDERBLAD (D)

*Author affiliations can be found in the back matter of this article

\section{(3)H}

Open Library of Humanities

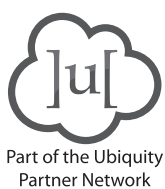

\section{ABSTRACT}

Kyle Barrett, "Illuminated: Antisyzygy" (8:40) - Blending film and painting, the video postulates several questions arising from the COVID-19 pandemic via the notion of "antisyzygy" or the in-between state in which, globally, society has found itself. Ilona Krawczyk, "More than one voice" (10:00) - Why do I feel connected to something which is beyond me, which comes from the past, which I don't understand? But there are those moments of unconsciousness that come out. Charlotta Grimfjord Cederblad, "Preparation" (10:17) - This video is an observation of what we prepare for when we prepare for performance, of how we prepare for the fact that we soon will be watched, of how we imagine that we are being watched and of what happens with the body when we think that no one is watching.

CORRESPONDING AUTHOR:

\section{Ben Spatz}

University of Huddersfield, UK b.spatz@hud.ac.uk

\section{KEYWORDS:}

Screen Production Research; embodied Practice; Scotland; Aotearoa; Deleuze

TO CITE THIS ARTICLE: Barrett, K, Krawczyk, I and Cederblad, CG. 2021. Three Illuminated Videos. Journal of Embodied Research, 4(2): 3 (29:33). DOI: https://doi. org/10.16995/jer.92 
VIDEO ARTICLE

Available to view here: https://doi.org/10.16995/jer.92.

Available for download here: https://doi.org/10.16995/jer.92.s1.

\section{VIDEO ARTICLE TRANSCRIPT}

[Note: This is a transcript of a video article. Individual elements from the transcript, such as metadata and reference lists, may appear more than once in the document, in order to be properly read and accessed by automated systems. The transcript can be used as a placeholder or reference when it is not possible to embed the actual video, which can be found by following the DOI.]

[00:10]

JER 4(2): 3 - "Three Illuminated Videos" (29:33)

Kyle Barrett (8:40)

"Illuminated: Antisyzygy"

Ilona Krawczyk (10:00)

"More than one voice"

Charlotta Grimfjord Cederblad (10:17)

"Preparation"

[00:20]

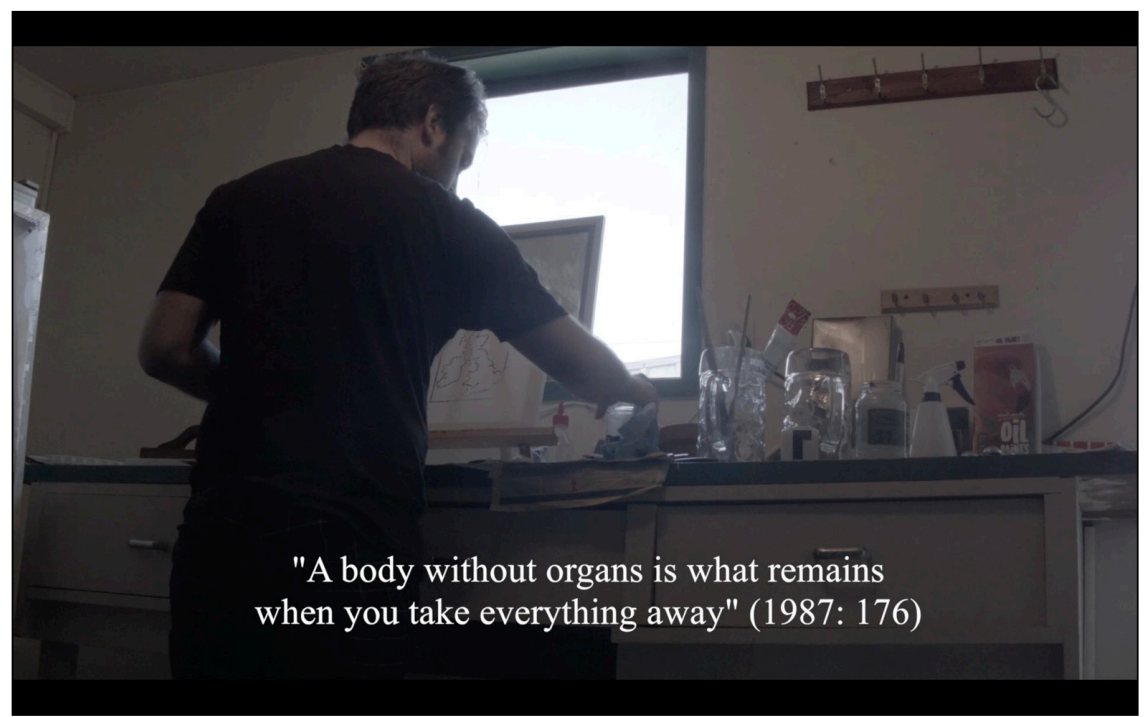

\section{Illuminated: Antisyzygy}

\section{Dr. Kyle Barrett}

Abstract

In the realms of Screen Production Research (SPR), an emerging field within the academy, filmmaking can be seen as "a parasitic creative practice, a hybrid medium that takes from and incorporates many other forms of expression" (Berkeley 2018: 31). It is within this "parasitic" notion that I wish to contextualise the video article.

Blending film and painting, the video postulates several questions arising from the COVID-19 pandemic. This project explores the notion of "antisyzygy" or the in-between state that, globally, society has found itself. The intent here is to embody questions from a Scottish ex-pat (myself) living and working in Aotearoa (New Zealand).

The painting represents a response to Scotland's current situation with another Independence Referendum being touted, which is once again developing out of frustrations from the lack of governing autonomy as, increasingly, the Break-Up of Britain appears to be on the horizon. 
Here, we locate a sense of an assemblage within Scotland, its identity being undermined and reshaped beyond its control, struggling to maintain its "Europeanness".

Filmed in a continuous, uncut shot, I draw attention to elements of the body as the painting comes to fruition. This, effectively, demonstrates that the body is a "mode of perception, [that] can contribute to increasingly rich understandings of human perception" (Lala and Kinsella 2011: 79). Throughout the running time are quotations, reflections, and illuminations that stem from this mixed approach of SPR and embodied practice.

This is in an effort to understand if meaning is generated through the practice or disseminated upon completion. The mix of sources range from Deleuze and Guattari, and their discussions of multiplicities, to filmmaker, poet, and author Margaret Tait whose poem "Elasticity" has poignancy given the current social, cultural, and political climate. Can we move on from the pandemic? Or will we return back to an unequal, fractured society?

Keywords: Screen Production Research, embodied Practice, Scotland, Aotearoa, Deleuze

Antisyzygy

"the culture of a nation-state and the culture of a stateless nation, within both of which the people of Scotland live"

(Gardiner 2006: 20)

Antisyzygy is the

"idea of duelling polarities within one entity"

(Martin 2009: 84)

Living in Aotearoa (New Zealand) -

a different kind of in-between state, several identities and opposites in one entity

The name Kyle has been deterritorialised to Kale

Aotearoa is an assemblage, a toi waihanga,

"a multiplicity which is made up of many heterogeneous terms and

which establishes liaisons, relations between them,

across ages, sexes and reigns - different natures"

(Deleuze and Parnet 1977: 69).

Deleuze and Guatarri discuss assemblages

"There are only multiplicities of multiplicities

forming a single assemblage"

(Deleuze and Guattari 1987: 39)

Scotland is an assemblage

Scottish

European

Pkeh

What is a British identity?

How was it assembled?

Steve Blandford writes:

British identity "was forged out of a sense

of isolation and an island fortress imagination" (2007: 9)

2020

Reshaped and reformed our understanding of isolation

And established new fortresses

Manuel DeLanda wrote that continental markets were assembling

With the "European Union being a prime example, but this is still an unfinished historical task, one that could fail if the interacting 
"national markets cease to give rise

to an emergent whole." (2016: 15).

This assemblage failed

Deleuze and Guattari wrote:

"A body without organs is what remains

when you take everything away" (1987: 176)

2021

Will more be taken away?

This canvas was a Body without Organs...

But what is it now?

In 1919, G. Gregory Smith understood assemblages

And antisyzygy

"Perhaps in the very combination of opposites [...]

we have a reflection of the contrasts which the Scot shows at every turn,

in his political and ecclesiastical history

"in his polemical restlessness, in his adaptability,

which is another way of saying that he has made

allowance for new conditions, in his practical judgement,

which is the admission that two sides

of the matter have been considered" (4).

Aotearoa/Scottish poet Sydney Goodsir Smith once wrote:

"And never the clock runs back,

The free days are owre;

"The world shrinks, we luik

Mair t'our maisters ilka hour -

"What yon lane boat I see

Daith an rebellion blind ma ee!” (1944)

2021 the year of the rebellion?

Do we come together?

Face oor maisters?

Where do we start?

Art

It challenges, argues, rebels against every maister

"The essence of art is

nothing less than the conservation of human experience itself"

(Crowther 2001: 7)

This experience must be expressed

We must use the 2020 body without organs

Filmmaker, poet, author Margaret Tait once wrote:

"Think of the word, elastic.

The real elastic quality is the being able to spring back

to the original shape" (1959)

Should we spring back in 2021 ?

Or start a new assemblage? 
The author declares that they have no competing interests.

References

Berkeley, L. (2018) “Lights, Camera, Research: The Specificity of Research in Screen Production," in C. Batty and S. Kerrigan (eds.) Screen Production Research: Creative Practice as Mode of Enquiry, Gewerbestrasse: Palgrave Macmillan, pp. 29-46

Blandford, S. (2007) Film, Drama, and the Break-Up of Britain, Bristol: Intellect.

Crowther, P. (2001) Art and Embodiment: From Aesthetics to Self-Consciousness, Oxford: Oxford University Press

DeLanda, M. (2016) Assemblage Theory, Edinburgh: Edinburgh University Press

Deleuze, G. and Parnet, C. (1977), Dialogues II, Paris: Flammarion

Guattari, G. and Guattari, F. (1987), A Thousand Plateaus, London: Bloomsbury Academic

Gardiner, M. (2006) From Trocchi to Trainspotting: Scottish Critical Theory Since 1960, Edinburgh: Edinburgh University Press

Park Lala, A. and Anne Kinsella, E. (2011) "Embodiment in Research Practices: The Body in Qualitative Research,” in J. Higgs, A. Titchen, D. Horsfall, and D. Bridges (eds.) Creative Spaces for Qualitative Researching: Living Research, Rotterdam: Sense Publishers, pp. 77-86

Goodsir Smith, S. (1944) "Largo," in M. Lindsay and L. Duncan (eds.) The Edinburgh Book of Twentieth-Century Scottish Poetry, Edinburgh: Edinburgh University Press, 2005, pp. 324

Martin, M. R. (2009) The Mighty Scot, New York: SUNY Press.

Smith, G. G. (1919) Scottish Literature: Character \& Influence, London: Macmillan \& Co. Limited. Tait, M. (1959) "Elasticity," in S. Neely (ed.) Margaret Tait: Poems, Stories, and Writings, Manchester: Carcanet Press Ltd, 2012, pp. 34

[09:13]

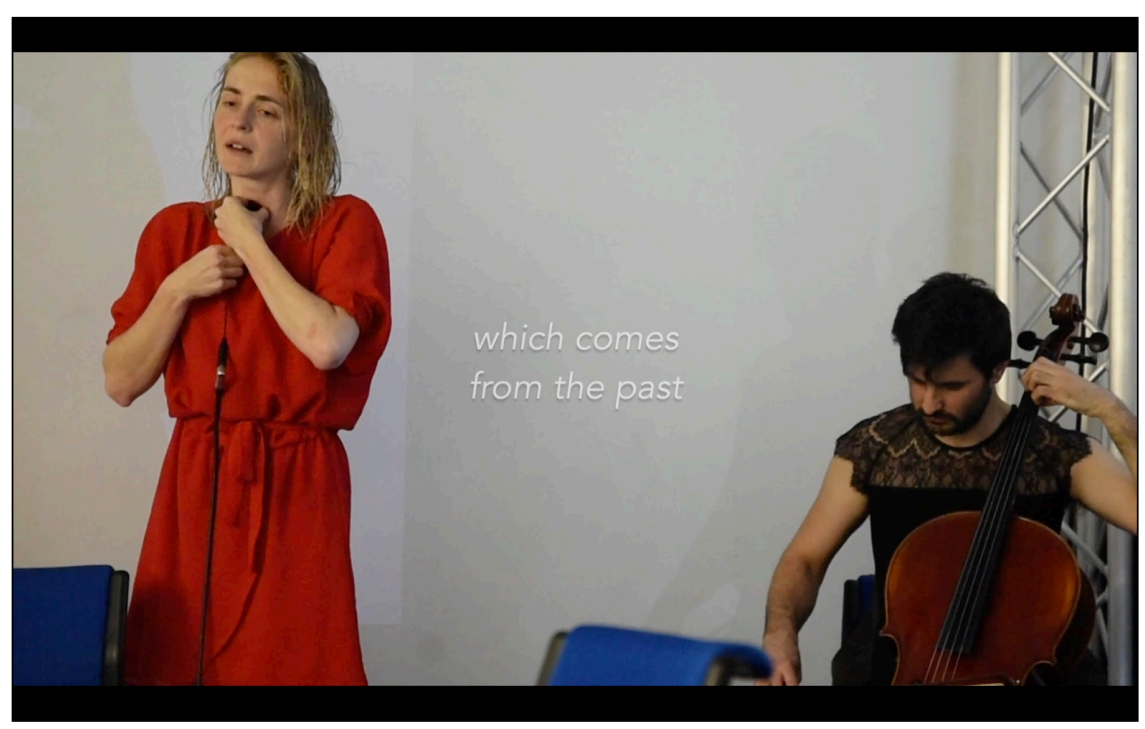

\section{MORE THAN ONE VOICE}

"illuminated" video article based on

Dreamvoice

performance - sound installation

by

Ilona Krawczyk

with 
Brice Catherin

Cristina Fuentes Antonazzi

David Velez

THE VOICE

"natural"

"authentic"

"open"

"free"

$\cdots$

I try to express it

or...

I try to understand

what my voice expresses.

"The voice manifests the unique being of each human being, and his or her [their] spontaneous self-communication according to the rhythms of a sonorous relation"

(Cavarero, 2005, 173).

In this sense, Cavarero's vocal ontology of uniqueness opposes the Cartesian "mute voice of consciousness" (Ibid. 173), categories of universalism, and philosophy of voice that considers one kind of normalised and defined culturally vocal expression as "right", "authentic", "natural", $\cdots$

I can say something without words.

My voice will sing

My voice will say

[vocalisation]

Except for open throat traditional Eastern European vocal technique specific to the country of my origin, in this spontaneous self-communication, I use Tahreer - a traditional Iranian singing technique and traditional Jewish singing.

I have no evidence that they are a part of my cultural heritage.

Who is speaking?

Who is singing?

Where does the voice come from?

Is it me singing?

Who is speaking, who is singing?

Where does the voice come from?

Is it me singing?

Why do I feel connected to something which is beyond me, which comes from the past, which I don't understand? But there are those moments of unconsciousness that come out.

Why? What? Who?

Why do I feel

connected 
to something

which is beyond me

which comes

from the past

which I don't understand

But there are

those moments of

unconsciousness

that come out

Why?

What?

Who?

"You don't know if it is you who is bringing about this voice or the voice that is bringing about you, and where the source of the sound is - in your mouth, [in] your chest, in your lungs, in your stomach, in your groin, or maybe in the room's walls, ceiling, or maybe in distant celestial bodies, in the crystal spheres of the universe" (Flaszen, 2010, 149).

How many voices are we?

How many voices are we?

Which voices we are using?

Which voices we are using?

Do we want our voices?

Do we want our voices?

What is good technique, what is bad technique?

What is good technique,

what is bad technique?

"Think of these sounds

that are usually considered "wrong",

such as pseudomultiphonics,

parasite sounds, accidental changes of pitches. ...

... Learn to control them,

to stabilise these so called "mistakes".

Love them, dig into them,

shape them, transform them

gently and constantly (...) ...

... Trust your sound, let it live the life it wants to live, just accompany it the best you can. Trust your instruments, your strings, your pipes, your vocal chords, they want to go a certain way, follow them, they know".

(Catherin, 2018, 19)

The voice - both as bodily event and as the exposition of that event - is the gesture which exhibits the relational uniqueness of being, which each time restages itself towards other (Di Matteo, 2015, 92).

\section{MORE THAN ONE VOICE}

“illuminated" video article

by Ilona Krawczyk with Brice Catherin,

Cristina Fuentes Antonazzi and David Velez.

Videography: Ben Spatz 
Catherin, B. (2018). Symphonie pour une femme seule. Score?

Cavarero, A. (2005). For more than one voice: Toward a philosophy of vocal expression. Stanford University Press.

Di Matteo, P. (2015). Performing the entre-deux: The capture of speech in (dis)embodied voices. In: K. Thomaidis, B. MacPherson (Eds.). Voice studies: Critical approaches to process, performance and experience (pp. 90-103). Routledge.

Flaszen, L. (2010). Grotowski \& company. Icarus.

\section{CITED SONG}

Prituri se planinata. Bulgarian folk song performed by Stefka Sabotinova.

Sourced from https://www.youtube.com/watch?v=og $4 \mathrm{zO} 4 \mathrm{zzOU}$

\section{DREAMVOICE}

performance - sound installation

performed and recorded 14.03.2019

in Studio 3 Patrick Stewart Building, University of Huddersfield

devised for Practice-as-Research on embodying voice in training and performance practice conducted by Ilona Krawczyk at University of Huddersfield thanks to North of England Consortium for Arts and Humanities (NECAH).

[19:12]

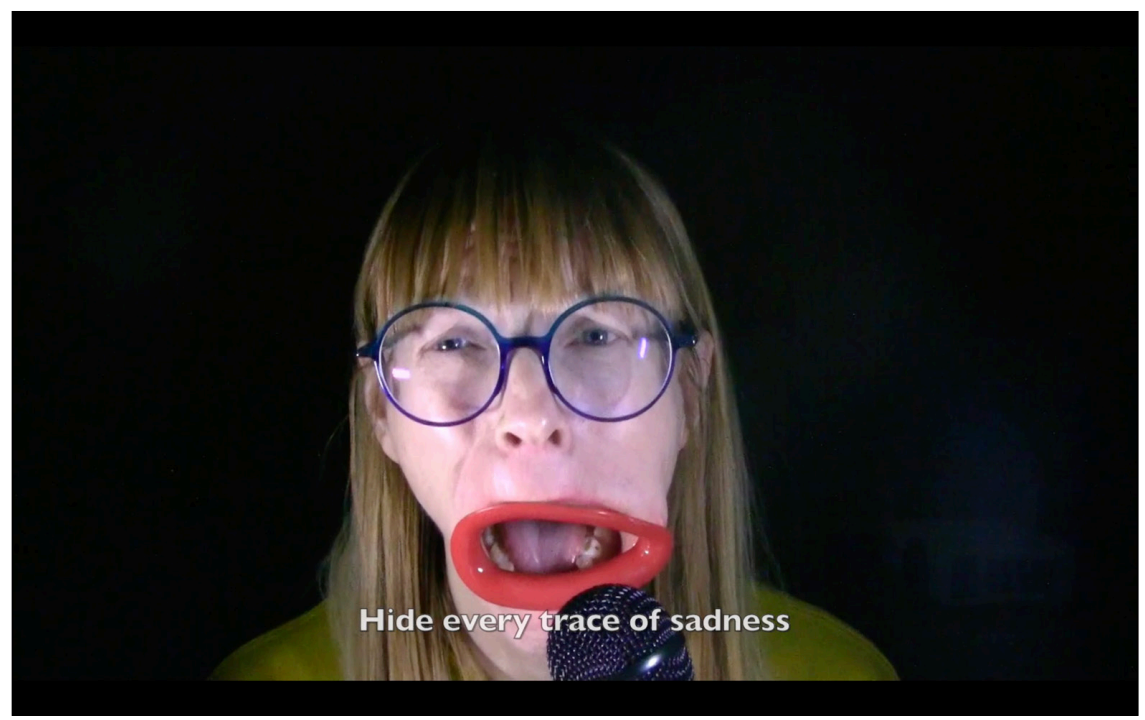

It is in and through the revelation of my being-as-object for the Other that I must be able to apprehend the presence of his being-as-subject.

Jean-Paul Sartre

\section{PREPARATION}

\section{BY CHARLOTTA GRIMFJORD CEDERBLAD}

I am preparing

I haven't really rehearsed

I have written texts to perform

I have given myself tasks

I have prepared four costume changes

I have set up props and equipment for sound and live video 
that I accidently

have put the camera on recording

I have chosen music to play

I don't decide until now

when I will play which music

The name of the performance is

If you look closely you will see me

The audience will enter

and leave the room

as they please during three hours

I will sit

with my back against the audience

They will only see my face

as a big live projection on the wall

[Lyrics to song:]

Smile though your heart is aching

Smile even though it's breaking

When there are clouds in the sky, you'll get by

If you smile through the fear and sorrow

Smile and maybe tomorrow

You'll see the sun come shining through

For you

Light up your face with gladness

Hide every trace of sadness

Although a tear may be ever so near

Smile though your heart is aching

Smile even though it's breaking

When there are clouds in the sky, you'll get by

If you smile through the fear and sorrow

Smile and maybe tomorrow

You'll see the sun come shining through

For you

Light up your face with gladness

Hide every trace of sadness

Although a tear may be ever so near

...if I tremble at the slightest noise, if each creak announces to me a look, this is because I am already in the state of being-looked-at.

Jean-Paul Sartre

[Lyrics to song:]

That's the time you must keep on trying

Smile, what's the use of crying

You'll find that life is still worthwhile

If you just smile

That's the time you must keep on trying

smile, what's the use of crying 
You'll find that life is still worthwhile

If you just smile

Perhaps it is impossible to understand one's own face. People who live in society have learned how to see themselves in mirrors as they appear to their friends.

Jean-Paul Sartre

[Charlotta, soundchecking:]
Mother
Babababa
Bababa
Babababa baba bababa

What happens soon is that I stop the recording, again by accident

I find the recording in my camera about two months later

It's not until then I understand that these ten minutes of preparing have been recorded

The whole preparation lasted for several hours

In order to make myself recognized by the Other, I must risk my own life.

Jean-Paul Sartre

PREPARATION

The recording took place at 13 festivalen, Konstepidemin in Göteborg, Sweden 2020-01-04

With and edited by:

Charlotta Grimfjord Cederblad

Recorded by Canon:

LEGRIA HF200

Music heard in the video:

September Sun by Kodomo

Aithos by Yair Etziony

Helix by Yair Etziony

Smile by Charlie Chaplin performed by Nat King Cole

Imperium Romanum by Yair Etziony

Pool by Pistol Disco

More by Nils Frahm

References:

Being and nothingness by Jean-Paul Sartre

Nausea by Jean-Paul Sartre

charlottagrimfjordcederblad.com

\section{COMPETING INTERESTS}

The authors have no competing interests to declare. 
AUTHOR AFFILIATIONS

Kyle Barrett (D) orcid.org/0000-0002-4395-5670

University of Waikato, Aotearoa, NZ

Ilona Krawczyk (iD) orcid.org/0000-0001-8920-3848

University of Huddersfield, UK

Charlotta Grimfjord Cederblad (iD orcid.org/0000-0003-1528-1362

Independent Researcher

\section{REFERENCES}

Berkeley, L. 2018. Lights, Camera, Research: The Specificity of Research in Screen Production. In: Batty, C and Kerrigan, S (eds.), Screen Production Research: Creative Practice as Mode of Enquiry. Gewerbestrasse: Palgrave Macmillan. pp. 29-46. DOI: https://doi.org/10.1007/978-3-31962837-0_3

Blandford, S. 2007. Film, Drama, and the Break-Up of Britain, Bristol: Intellect.

Catherin, B. 2018. Symphonie pour une femme seule. Score?

Cavarero, A. 2005. For more than one voice: Toward a philosophy of vocal expression. Stanford University Press.

Crowther, P. 2001. Art and Embodiment: From Aesthetics to Self-Consciousness, Oxford: Oxford University Press. DOI: https://doi.org/10.1093/acprof:oso/9780199244973.003.0010

DeLanda, M. 2016. Assemblage Theory, Edinburgh: Edinburgh University Press.

Deleuze, G and Parnet, C. 1977. Dialogues II, Paris: Flammarion.

Di Matteo, P. 2015. Performing the entre-deux: The capture of speech in (dis)embodied voices. In: Thomaidis, K, MacPherson, B (eds.). Voice studies: Critical approaches to process, performance and experience. Routledge. pp. 90-103.

Flaszen, L. 2010. Grotowski \& company. Icarus.

Guattari, G and Guattari, F. 1987. A Thousand Plateaus, London: Bloomsbury Academic.

Gardiner, M. 2006. From Trocchi to Trainspotting: Scottish Critical Theory Since 1960, Edinburgh: Edinburgh University Press. DOI: https://doi.org/10.3366/edinburgh/9780748622320.001.0001

Goodsir Smith, S. 1944. Largo. In: Lindsay, M and Duncan, L (eds.), The Edinburgh Book of Twentieth-Century Scottish Poetry. Edinburgh: Edinburgh University Press, 2005. pp. 324.

Lala, AP and Kinsella, EA. 2011. Embodiment in Research Practices: The Body in Qualitative Research. In: Higgs, J, Titchen, A, Horsfall, D and Bridges, D (eds.), Creative Spaces for Qualitative Researching: Living Research. Rotterdam: Sense Publishers. pp. 77-86. DOI: https://doi. org/10.1007/978-94-6091-761-5_8

Martin, MR. 2009. The Mighty Scot. New York: SUNY Press.

Prituri se planinata. Bulgarian folk song performed by Stefka Sabotinova. Sourced from https:// www.youtube.com/watch?v=og $4 \mathrm{zO} 4 \mathrm{fzSOU}$.

Smith, GG. 1919. Scottish Literature: Character \& Influence, London: Macmillan \& Co. Limited.

Tait, M. 1959. Elasticity. In: Neely, S (ed.), Margaret Tait: Poems, Stories, and Writings. Manchester: Carcanet Press Ltd, 2012. pp. 34.
TO CITE THIS ARTICLE: Barrett, K, Krawczyk, I and Cederblad, CG. 2021. Three Illuminated Videos. Journal of Embodied Research, 4(2): 3 (29:33). DOI: https://doi. org/10.16995/jer.92

Submitted: 24 July 2021

Accepted: 24 July 2021

Published: 11 October 2021

COPYRIGHT:

(c) 2021 The Author(s). This is an open-access article distributed under the terms of the Attribution-NonCommercialNoDerivatives 4.0 International License (CC BY-NC-ND 4.0), which permits unrestricted use, distribution, and reproduction in any medium, provided the original author and source are credited. See https:// creativecommons.org/licenses/ by-nc-nd/4.0/.

Journal of Embodied Research is a peer-reviewed open access journal published by Open Library of Humanities. 